удК 343.982 .33

DOI https://doi.org/10.32837/yuv.v0i3.2198

Г. Гончарук,

провідний науковий співробітник

Українського науково-дослідного інституту спеціальної техніки та судових експертиз Служби безпеки України

\title{
ЩОДО ДОЦІЛЬНОСТІ СТВОРЕННЯ ТА ВИКОРИСТАННЯ КРИМІНАЛІСТИЧНИХ КОЛЕКЦІЙ БПЛА
}

\begin{abstract}
Постановка проблеми. Наслідком запровадження у військову та цивільну діяльність нових видів високотехнологічних винаходів $€$ те, що рано чи пізно ці вироби стають потенційними об'єктами кримінальної діяльності. Науково-технічний прогрес зумовлює збільшення числа об'єктів кримінальних злочинів та судових експертиз, що своєю чергою вимагає постійного розвитку кримінології та експертології. Яскравим прикладом об'єктів, що пройшли шлях від військового до цивільного застосування i врешті стали предметом кримінального застосування, є безпілотні літальні апарати.

3 огляду на можливі сценарії злочинного, протиправного або необережного використання БПЛА з метою встановлення фактичних даних (фактів) та обставин певних явищ та процесів, що мають значення для кримінального провадження, вирішення господарської, адміністративної справи, справи про адміністративне правопорушення постала необхідність проведення експертних досліджень і судової експертизи БПЛА. Ефективність проведення будь-якого експертного дослідження залежить від обсягу знань спеціаліста, який проводить експертизу. Зважаючи, що судова експертиза БПЛА перебуває на етапі свого становлення, актуальним $€$ питання підвищення рівня інформаційного забезпечення проведення експертних досліджень БПЛА. Історія
\end{abstract}

розвитку судової експертологіі свідчить, що важливим засобом інформаційного забезпечення експертних досліджень БПЛА може стати створення та використання криміналістичних обліків та криміналістичних колекцій БПЛА.

Аналіз останніх досліджень i публікацій. Проблематиці кримінальної реєстраціі, створення, використання та вдосконалення криміналістичних обліків як джерела криміналістично значущої інформації приділяли увагу такі українські науковці, як В.О. Приходько [2-5], С.В. Кадук [7], Н.I. Клименко [10]. Вагомий внесок стосовно теоретичних основ інформаційно-довідкового забезпечення розслідування злочинів своєю працею зробив В.В. Бірюков [1]. Вперше увів у вітчизняний науковий дискурс питання створення та використання криміналістичних обліків БПЛА старший викладач Національної академії внутрішніх справ P.M. Примак [6].

Виклад основного матеріалу. Розвиток криміналістичної реєстрації органічно пов'язаний з теорією криміналістичної ідентифікації, вченням про механізм слідоутворення і спосіб скоєння злочинів, про фіксацію доказової інформаціі.

Вагоме значення мають науково обгрунтовані теоретичні положення про закономірності та причинневу зумовленість (детермінованість) способів скоєння злочинів, повторювано- 
сті засобів, методів і механізмів злочинних дій, а отже, і слідів злочину.

Базується криміналістична реєстрація на використанні теорії ідентифікації, судової фотографіі, дактилоскопіі, словесному портреті та інших наукових даних.

Натепер криміналістичні обліки безпосередньо не передбачені вітчизняним кримінально-процесуальним законодавством. Проте порядок ї ведення у загальних рисах визначено вимогами Кримінально-процесуального кодексу України, що стосуються правил фіксації, вилучення й зберігання речових доказів, отримання зразків для порівняльного дослідження, залучення спеціаліста, призначення і проведення експертиз.

Криміналістичні обліки - це сукупність інформаційно-пошукових систем, що створені та функціонують у правоохоронних органах 3 метою забезпечення процесу розслідування злочинів, певною інформацією про об’єкти підвищеного криміногенного ризику, яка становить їх масиви [1, с. 327].

Об'єкти криміналістичних обліків - це злочини, люди (у тому числі ix трупи), а також різноманітні предмети матеріального світу, що в минулому були якимось чином причетні до злочинів або подібні до яких, часто стають об'єктами злочинного посягання чи використовуються злочинцями як знаряддя, зброя тощо, інформація стосовно яких може сприяти розкриттю злочинів [1, с. 349].

Розвиток наукової думки дозволив сформувати класифікацію криміналістичних обліків. Так, за функціональним призначенням криміналістичні обліки поділяються на три групи:

1) оперативно-розшукового призначення;

2) оперативно-довідкового призначення;

3) довідково-допоміжного призначення.

Проте натепер ця класифікація не $є$ усталеною.
Криміналістичні обліки оперативно-розшукового призначення - це обліки, що містять інформацію стосовно об'єктів, причетних до нерозкритих злочинів, а також конкретних об’єктів, які становлять оперативний інтерес, що безпосередньо призначена сприяти ї установленню за штучними чи власними ознаками [1, с. 376].

Правовою основою функціонування (формування, ведення та використання) криміналістичних обліків є Конституція України, закони України, нормативно-правові акти Президента України та Кабінету Міністрів України, нормативно-правові акти МВС. Функціонування криміналістичних обліків грунтується на принципах законності, гуманізму, поваги до прав та свобод людини і громадянина, наукової обгрунтованості, всебічності та повноти застосування спеціальних знань.

Джерелами формування криміналістичних обліків є об'єкти (ї копї̈, зображення) та (або) відомості про них, що надходять $з$ органів дізнання, досудового слідства, прокуратури, судів, органів та підрозділів, які відповідно до чинного законодавства мають право здійснювати оперативно-розшукову діяльність, зокрема Служби безпеки України та Служби зовнішньої розвідки України.

Криміналістичні обліки створюються 3 метою використання їх для запобігання, виявлення, розкриття i розслідування злочинів та інших правопорушень у разі здійснення оперативно-розшукової діяльності, дізнання та досудового слідства, а також 3 метою підвищення рівня інформаційного забезпечення проведення експертних досліджень [8].

Наявність великого масиву наукових знань у галузі криміналістичної реєстрації, а також практичний досвід застосування криміналістичної реєстрації в діяльності органів внутрішніх справ України дозволили розробити та в 2009 році ввести в дію 
Інструкцію 3 організації функціонування криміналістичних обліків експертної служби МВС України (далі Інструкція) [8]. Попередня інструкція, яка стосувалася питання ведення криміналістичних обліків, була введена в дію в 1994 році. Тобто Інструкція 2009 року враховувала результати наукових досліджень і практичної діяльності в галузі криміналістичної реєстрації за період у 15 років. Інструкція визначає основні положення формування системи реєстрації об'єктів та (або) відомостей про них, порядок їх використання у розкритті, розслідуванні скоєних злочинів та профілактиці злочинності.

На сучасному етапі криміналістичні обліки включають такі види, як:

- трасологічний облік;

- дактилоскопічний облік;

- балістичний облік;

- облік холодної зброї;

- облік грошових знаків, бланків документів, цінних паперів та пластикових платіжних карток;

- облік осіб за ознаками зовнішності;

- вибухотехнічний облік;

- пожежно-технічний облік;

- облік наркотичних засобів, психотропних речовин, їх аналогів та прекурсорів;

- облік генетичних ознак людини;

- облік записів голосів та мовлення осіб;

- облік ідентифікаційних позначень транспортних засобів та реквізитів документів (підписів, печаток, штампів);

- облік матеріалів, речовин та виробів.

Зазначені обліки складаються 3 оперативно-пошукових та (або) інформаційно-довідкових колекцій.

На етапі формування пропозицій щодо доцільності створення та використання криміналістичного обліку БПЛА зауважимо, що слід зосередитися на створенні інформаційно-довідкових колекцій як додаткового, проте істотного джерела знань для спеціа- лістів, які проводять експертні дослідження БПЛА. З'ясування питання доцільності створення оперативно-розшукових колекцій вбачається віднести до перспективних напрямів досліджень.

Інформаційно-довідкові колекціі є складовою частиною криміналістичних обліків інформаційно-довідкового призначення. Криміналістичні обліки інформаційно-довідкового призначення - це обліки, що призначені забезпечувати процес розслідування різноманітною інформацією про об'єкти, причетні до злочину, яка може бути корисною для вирішення завдань, що виникають у процесі розслідування кримінальних справ [1, с. 377]. С.В. Кадук у своїх працях, досліджуючи криміналістичні обліки інформаційно-довідкового призначення, застосовує поняття довідково-допоміжних обліків [7] та криміналістично-довідкових колекцій [11].

До довідково-допоміжних криміналістичних обліків належать колекції та каталоги різноманітних об’єктів, які використовуються як зразки для порівняння у разі проведення експертиз і досліджень, а також у розшуковій діяльності для вирішення класифікаційних завдань [1, с. 378-379]. Такі об’єкти, як правило, не пов'язані зі злочинною діяльністю. Утім подібні до них об'єкти досить часто або стають предметами злочинних посягань, або використовуються як знаряддя для подолання перешкод, для заподіяння тілесних ушкоджень, убивств людей. Тому вони часто є об’єктами криміналістичних досліджень.

Основу цієі групи криміналістичних обліків становлять різноманітні колекції чи каталоги зразків для порівняльного дослідження. Колекції довідкового і натурного характеру, як правило, використовуються 3 метою інформаційного забезпечення пізнавальної діяльності спеціаліста-експерта. У судовій експертизі вони мають два види: натурні колекції 
й описові форми [10, с. 98]. Хоча ці обліки безпосередньо не допомагають у розкритті конкретних злочинів, однак вони сприяють вирішенню інших не менш важливих завдань, які виникають у процесі розслідування. Наприклад, для встановлення належності об'єкта до певної категорії, визначення групи подібних об'єктів тощо. Свого часу П.М. Заблоцький став ініціатором створення колекції саморобної вогнепальної зброї, яка сприяє вирішенню низки завдань, що виникають у розслідуванні злочинів, пов'язаних із використанням цієї категорії зброї. Натурні колекції саморобної вогнепальної зброї дозволяють здійснити порівняльне дослідження об'єктів і за результатами його дійти висновку про єдине походження об'єктів [1, с. 378]. Минуло майже 40 років і науково-технічний прогрес, а разом з ним злочинний світ спонукають нас до необхідності проведення досліджень, спрямованих на створення довідково-допоміжних обліків безпілотних літальних апаратів, а також інших автономних, дистанційно-керованих апаратів і пристроїв, які все частіше стають знаряддям злочину. Зважаючи, що Служба безпеки України першою в нашій країні запровадила судову експертизу БПЛА [9], а отже, вже накопичила певний досвід у цій царині, завдання щодо ведення таких обліків вважається за доцільне покласти на експертну установу СБУ.

Дослідження питання створення та запровадження нового виду криміналістичних обліків має грунтуватися на результатах наукових розробок з виявлення і класифікації загальних і індивідуальних ознак, які характеризують об'єкти обліків, на загальних положеннях теорії криміналістичної ідентифікації, діагностики і встановлення групової належності.

Зважаючи, що нині не доводиться говорити про наявність великої кількості БПЛА, які стали об'єктами кримінальних проваджень, але беручи до уваги, що виробники БПЛА не надають і не будуть надавати повного доступу до інформації про характеристики та ознаки БПЛА, доцільно вести мову про створення натурних (предметних) колекцій.

Для підготовки пропозицій щодо запровадження криміналістичного обліку БПЛА вважається за доцільне орієнтуватися на теоретичні основи трасологічного обліку, вибухотехнічного обліку як на обліки, що натепер за своєю природою є найбільш релевантними до обліку БПЛА. 3 огляду на можливість створення БПЛА в кустарних умовах та наявність «саморобних» БПЛА, слід також врахувати теоретичні основи та досвід обліку саморобної вогнепальної та холодної зброї.

Відповідно до Інструкції інформаційно-довідкові колекції, які належать до трасологічного обліку, складаються зі зразків знарядь зламу, запірних та запірно-пломбувальних пристроїв (їх копій, зображень або відомостей про них), а також відомостей про взуття, транспортні засоби та формується із зразків знарядь зламу, запірних та запірно-пломбувальних пристроїв, частин транспортних засобів (шини, фарне скло тощо), виробів масового виробництва (або зображень та відомостей про них) [8].

Довідково-допоміжні колекції створюються шляхом збирання, накопичення та систематизації однорідних об'єктів або інформації про них за ідентифікаційними ознаками.

Довідково-допоміжні колекції мають певну класифікацію. За основу цієї класифікації мають бути взяті ознаки, що відображають, передусім, ті ознаки та властивості об'єктів, які під час відповідного їх дослідницького (експертного чи слідчого) класифікаційного застосування допоможуть визначити їх марку, систему та інші показники. Так, за способом формування (побудови) колекцій криміналістично-довідкові колекції можна поділяти на: а) предметні; б) зображувальні; в) типові; г) інфор- 
маційно-комп'ютерні [12]. Така класифікація криміналістичних колекцій $€$ найбільш широкою. В різних джерелах предметні колекціі також називають натурними колекціями, або матеріальними колекціями.

Таким чином, досліджуючи питання запровадження довідково-допоміжних колекцій БПЛА, зробимо спробу сформулювати теоретичні основи формування колекцій БПЛА кожного виду, виходячи з наведеної вище класифікації колекцій за способом формування.

Натурна (предметна) колекція компонентів, частин (уламків, фрагментів) БПЛА формується 3 конструкційних елементів БПЛА (фюзеляж, крило, хвостове оперення, двигун), з елементів корисного навантаження БПЛА (електронні, оптико-електронні, радіоелектронні засоби), 3 елементів наземних пристроїв керування. Джерелом поповнення колекції стануть об'єкти, які фігурували в кримінальних провадженнях та в експертній практиці.

Зображувальна (модельна) колекція БПЛА формується з фотографій, відеозаписів, технічної документації БПЛА та їх складових частин, наземних станцій управління, фірмових планок, бортових номерів, отриманих 3 мережі Інтернет, 3 виставкових заходів, від виробників, від розвідувальних органів тощо. На сучасному етапі розвитку інформаційних технологій зображувальна колекція $€$ частиною інформаційно-комп'ютерної колекції, тому що вона обов'язково має бути доповнена відповідною базою даних про виробників, користувачів БПЛА, технічними характеристиками БПЛА, гіперпосиланнями на відповідну інформацію в мережі Інтернет. Беручи до уваги, що у системах відеоспостереження, системах організації дорожнього руху, в пошукових сервісах Інтернет широко й успішно використовуються програмні модулі інтелектуального розпізнавання зображень, доцільно доповнити зображувальну колекцію БПЛА системою штучного інтелекту, яка здатна в автоматичному режимі співставляти зображення та (або) фрагменти зображень для ідентифікації об’єктів.

Можливість використовувати натурні та комп'ютерно-інтегровані криміналістичні колекції БПЛА значно полегшить проведення судових експертиз та експертних досліджень БПЛА. Нижче наведено приклади таких класифікаційних завдань (завдань групової ідентифікаціі). Визначення належності технічних засобів до компонентів БПЛА певного призначення. Визначення типу БПЛА за компонентами (частинами), виявленими на місці події. Наприклад, визначення класу БПЛА за уламком крила (за частинами двигуна). Визначення дальності дії каналу управління за радіоелектронним блоком БПЛА. Орієнтовний перелік вирішуваних питань (класифікаційні завдання): До якого типу БПЛА належать надані компоненти (частини)? Чи можуть належать надані технічні засоби до цільового навантаження розвідувальНого БПЛА?

Висновки. На етапі становлення судової експертизи БПЛА, щоб не залишити поза увагою наявний позитивний і негативний досвід, слід враховувати теоретичний та методологічний апарат судових експертиз, які вже пройшли етап свого становлення. Поряд 3 розробленням спеціалізованих методик експертних досліджень БПЛА важливим етапом розвитку судової експертизи БПЛА має стати розробка теоретичного підгрунтя та практичних рекомендацій щодо створення і запровадження криміналістичних обліків БПЛА у формі довідково-допоміжних колекцій БПЛА. При цьому слід розробляти пропозиції щодо ведення таких колекцій як у вигляді натурних (предметних) колекцій, так і у вигляді зображувальних (модельних) колекцій БПЛА. Опрацьовуючи питання створення

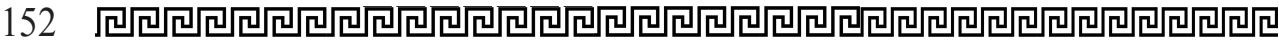


модельних колекцій БПЛА, слід враховувати останні досягнення в галузі інформаційних технологій та штучного інтелекту. 3 метою забезпечення належного правового підгрунтя ведення та використання криміналістичних колекцій БПЛА слід розробляти пропозиції щодо внесення змін до наявних нормативно-правових документів. До перспективних напрямів досліджень за окресленою тематикою слід віднести питання доцільності створення оперативно-розшукових колекцій БПЛА та інших безпілотних (дистанційно-керованих) пристроїв.

Ефективність проведення будьякого експертного дослідження залежить від обсягу знань спеціаліста, який проводить експертизу. Зважаючи, що судова експертиза БПЛА перебуває на етапі свого становлення, актуальним є питання підвищення рівня інформаційног забезпечення проведення експертних досліджень БПЛА. Важливим засобом інформаційного забезпечення експертних досліджень має стати використання криміналістичних обліків та криміналістичних колекиій БПЛА. Умовою запровадження криміналістичних обліків БПЛА є створення належного правового підтрунтя.

Досліджуеться питання створення та запровадження довідково-допоміжних колекиій БПЛА як форми криміналістичного обліку інформаційно-довідкового призначення. Довідково-допоміжні колекиії БПЛА мають стати додатковим джерелом інформаціі у разі проведення експертних досліджень. За способом формування довідково-допоміжні колекції поділяються на натурні та зображувальні.

Натурна (предметна) колекиія компонентів, частин (уламків, фрагментів) БПЛА формується 3 конструкиійних елементів БПЛА, з елементів корисного навантаження БПЛА (електронні, опти- ко-електронні, радіоелектронні засоби), з елементів наземних пристроїв керування. Джерелом поповнення колекиї стануть об'єкти, які фігурували в кримінальних провадженнях та в експертній практиці. Довідково-допоміжні колекиіі створюються иляхом збирання, накопичення та систематизаиіі однорідних об'єктів або інформаціі про них за ідентифікаційними ознаками.

Зображувальна (модельна) колекиія БПЛА формується 3 фотографій, відеозаписів, технічної документаиї БПЛА та їх складових частин, наземних станиій управління, фірмових планок, бортових номерів, отриманих 3 мережі Iнтернет, з виставкових заходів, від виробників, від розвідувальних органів тощо. На сучасному етапі розвитку інформаційних технологій зображувальна колекція є частиною інформаційно-комп'ютерної колекиії, тому що вона обов'язково має бути доповнена відповідною базою даних про виробників, користувачів БПЛА, технічними характеристиками БПЛА, гіперпосиланнями на відповідну інформацію в мережі Iнтернет.

Ключові слова: БПЛА, експертні дослідження, криміналістичні обліки, криміналістичні колекції, довідково-допоміжні обліки.

\section{Honcharuk H. EXPEDI- ENCY OF CREATION AND USE CRIMINALISTICS COLLECTIONS OF UNMANNED AERIAL VEHICLES}

The effectiveness of any expert study depends on the amount of a specialist's knowledge conducting the expertise. Given that the forensic expertise of the unmanned aerial vehicles is at the stage of its formation, increasing the level of information support for conducting expert research of the $U A V$ is relevant these days. 
Forensic records and forensic collections of UAVs should be an important means of providing information for expert research. The condition for the introduction of forensic $U A V$ records is the creation of a proper legal basis. The creation and introduction of reference and auxiliary collections of UAVs as a form of forensic accounting of information and reference purposes is investigated. Reference and support collections of UAVs should become an additional source of information when conducting expert research. According to the method of formation, reference and auxiliary collections are divided into full-scale and pictorial.

Natural (subject) collection of UAVs components, parts (debris, fragments) is formed from unmanned aerial vehicles structural elements, from unmanned aerial vehicles payload elements (electronic, optoelectronic, radio-electronic means), from elements of ground control devices. The source of replenishment of the collection will be the objects that appeared in criminal proceedings and expert practice. Reference and auxiliary collections are created by collecting, accumulating, and systematizing homogeneous objects or information about them based on identification.

Pictorial (model) collection of UAVs is formed from photographs, videos, technical documentation of $U A V s$ and their components, ground control stations, branded plates, board numbers obtained from the Internet, from exhibition events, from manufacturers, from intelligence agencies, etc. At the current stage of the development of information technology, the image collection is part of the information-computer collection because a database of manufacturers must supplement it, UAV users' technical characteristics, hyperlinks to relevant information on the Internet.
Key words: unmanned aerial vehicles, forensic expertise, criminalistics databases, criminalistics collections, criminalistics reference databases.

\section{Лiтература}

1. Бірюков B.B. Теоретичні основи інформаційно-довідкового забезпечення розслідування злочинів : монографія. Луганськ : РВС ЛДУВС ім. Е.О. Дідоренка, 2009. 664 c.

2. Приходько В.О. Криміналістичні обліки розшукового призначення Експертної служби МВС України - джерела криміналістично значущої інформації. Порівняльно-аналітичне право. 2018. № 3. C. 281-284.

3. Приходько В.О. Криміналістичні обліки оперативно-розшукового призначення: сучасний стан $i$ тенденції. Сучасні тенденції розвитку криміналістики та кримінального процесу. 2017. C. $168-170$.

4. Приходько В.О. Правові підстави використання криміналістичних довідково-допоміжних обліків. Науковий вісник публічного та приватного права. 2017, випуск 6, том 4. C. 133-137.

5. Приходько В.О. Криміналістичні обліки Департаменту інформаційно-аналітичної підтримки Національної поліції України. Jurnalul juridic naţional: teorie şi practică = Национальный юридический журнал: теория и практика. 2018, № 4, mом 2. C. 122-127.

6. Примак Р.М. Щодо можливості створення та використання криміналістичних обліків безпілотних літальних пристроїв. Теорія та практика судово-експертної діяльності. 2018. C. $348-350$.

7. Кадук С.В. Довідково-допоміжні обліки. Іх місце у системі криміналістичної реєстрації. Актуальні проблеми вдосконалення чинного законодавства України. 2010. Bun. 23. С. 222-226.

8. Наказ МВС України від 10 вересня 2009 № 390 «Про затвердження Інструкції з організаціі та функціонування криміналістичних обліків експертної служби МВС». / Верховна Рада України. URL: http://zakon.rada.gov.ua/laws/ show/z0963-09\#Text (Јата звернення: 16.06.2021).

9. Наказ ЦУ СБУ віо 29 травня 2015 № 371 «Про затвердження Інструк- 


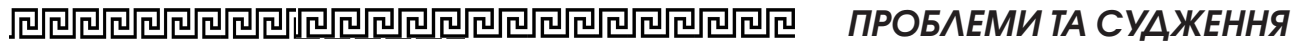

иіï про призначення та проведення судових експертиз та експертних досліджень у системі Служби безпеки Украӥни». / Верховна Рада України. URL: https://zakon.rada.gov.ua/laws / show/z0738-15\#Text (даma звернення: 29.03.2021).

10. Клименко H.I. Судова експертологія: курс лекиій : навчальний посібник. Київ : Видавничий дім «Iн Юре», 2007. C. 98.
11. Кадук C.B. Система та види криміналістично-довідкових колекиій. URL: http: / / law-dep.pu.if.ua / conference2014 / articles/kaduk.pdf (даma звернення: 16.06.2021).

12. Бірюков В.В. Облікова інформація в розслідуванні. Загальна структура та класифікаиія інформаиійних систем. Науковий вісник Львівського державного університету внутрішніх справ. 2009. Bun. 3. C. 339-346. 